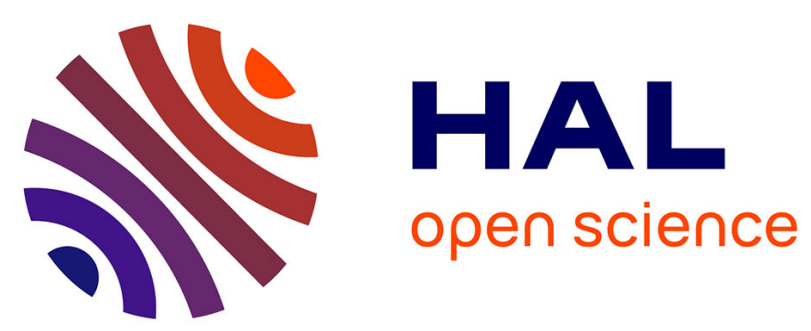

\title{
ERRATUM : Fixed dimensional computation of critical transport properties of fluids
}

\author{
G. Paladin, L. Peliti
}

\section{To cite this version:}

G. Paladin, L. Peliti. ERRATUM : Fixed dimensional computation of critical transport properties of fluids. Journal de Physique Lettres, 1984, 45 (6), pp.289-289. 10.1051/jphyslet:01984004506028900 . jpa-00232344

\section{HAL Id: jpa-00232344 https://hal.science/jpa-00232344}

Submitted on 1 Jan 1984

HAL is a multi-disciplinary open access archive for the deposit and dissemination of scientific research documents, whether they are published or not. The documents may come from teaching and research institutions in France or abroad, or from public or private research centers.
L'archive ouverte pluridisciplinaire HAL, est destinée au dépôt et à la diffusion de documents scientifiques de niveau recherche, publiés ou non, émanant des établissements d'enseignement et de recherche français ou étrangers, des laboratoires publics ou privés. 


\title{
ERRATUM
}

\section{Fixed dimensional computation of critical transport properties of fluids}

\author{
G. Paladin and L. Peliti \\ (J. Physique Lett. 43 (1982) L-15 - L-20)
}

The expression of the exponent function $\eta_{\bar{\eta}}$ (Eq. (8), page L-16) is marred by a trivial error. It should read $-(\pi / 80) f$, instead of $-(\pi / 40) f$. This leads to the following modifications :

page L-16, Eq. (9) should read $f^{*}=\frac{3}{\pi} \frac{80}{83}, w^{*}=0$;

Eq. (10) should read $-\eta_{\lambda}^{*}=x_{\lambda}+\eta=\frac{80}{83} \simeq 0.96$;

Eq. (11) should read $-\eta \frac{*}{\bar{\eta}}=x_{\bar{\eta}}=\frac{3}{83} \simeq 0.04$;

page L-17, Eq. (14) should $\operatorname{read} \bar{R}=1.0375$;

page L-18, Eq. (25) should read $R_{k} / R=80 / 83=-\eta_{\lambda}^{*}=1-x_{\bar{\eta}}$.

The discussion of the scaling function $(\S 4)$ is not affected by this mistake. 